\title{
The Modelling Concept of Volume and Duration of Parking for Various Types of Landuse in Surabaya
}

\author{
Anak Agung Gde Kartika ${ }^{1}$, Indrasurya B. Mochtar ${ }^{2}$, Hera Widyastuti \\ ${ }^{a}$ Ph.D.Student of ITS, Jurusan T Sipil ITS, Surabaya 60111, Indonesia \\ ${ }^{b}$ Lecturer of ITS, T Sipil ITS, Surabaya 60111, Indonesia \\ *Corresponding author: a.agung.kartika@gmail.com
}

\begin{abstract}
Both parking fee and parking tax are the potential income for most local authorities in Indonesia since they are considered as the parts of of local authority's revenue (Pendapatan Asli Daerah, PAD). However, currently many local authorities including that in Surabaya has a problem in determining target as well as the achievement of annual parking revenue. This situation takes place due to the lack of reliable method to estimate the parking revenue including both parking fee and parking tax either on-street parking nor off-street parking. Meanwhile, there are growing investments of public and private facilities in many capital cities of both regency and provincy including apartments, hotels, malls, campus, hospitals, convention buildings, terminals, offices, restaurants and mixed uses in which many parking spaces will be provided to support their activities later on. The providing of new parking spaces will therefore potentially contribute to the local authorities's revenue as the consequences. Main variable to contribute the parking revenue are the number of parked vehicle as well as the parking duration (when progressive tariff is applied). The concept of both number of parked vehicle and parking durations for several landuses will be introduced in this paper so that they can be elaborated more in depth as a mathematical model. Furthermore they can be used as references for estimating the anual parking revenue of local authotities as the part of local authorities revenue (PAD). Moreover, these models will be useful for parking facilities investors to analyse the their financial investment.
\end{abstract}

Keywords—Parking, Off-street, Landuses, Local Government's Revenue (PAD), Surabaya.

\section{INTRODUCTION}

$\mathrm{C}$ urrently, parking supply and parking restriction are commonly used as the vehicle movement restriction (Darmaningtyas, 2011 and Aucland Transport, 2016). On the other hand, parking activity is one of the potential local government's revenue especially for those having high car ownership as well as high economy activity. Eventhough, compared to other local tax components, parking revenue is not the biggest share (Arditia and Nuswantara, 2013).

However, it is publicly known that in most of local governments in Indonesia, including Jakarta and Surabaya, the parking management of both on-street and off-street, in terms of revenue collected, is indicated as less than supposed to be obtained due to the absence of collecting system method especially parking revenue prediction tools. In example, in Surabaya, the target for annual parking revenue in 2014 is IDR 80 billion while the real income is only IDR 48 billions which is only $60 \%$ of the targeted revenue (Suarasurabaya.net, 2016). This low realisation parking revenue has lasted for long time period, it is can be proved by following records; according to Beritasurya (2012), the realisation percentage of on-street parking revenue in 2009 and 2010 are $65.5 \%$ and $51.73 \%$ respectively. Meanwhile, Hakim (2014) mentioned that the lost of parking revenue is $40 \%$. Moreover, Arditia and Nuswantara mentioned that within the period of 2008-2011 the realisation of total parking tax is always below the target.
The absence of system to predict the potential parking revenue due to this following reasons; first, the real number of parked vehicle is not yet recorded totally, second, in the real situation, the parking tariff per vehicle is not applied uniformly (higher parking fee is found), third, progressive tariff is applied in some facilities which make parking duration is important, fourth, there is no guidance regarding the collecting parking tax for both on-street and off-street parking, fifth, the variation of landuse influencing parking characteristic, sixth, the numerous non-registered parking facilities are identified due to the development of the city, seventh, many freeparking facilities in both goverment office and private facility still charge parking fee to users. Therefore, this paper will suggest the modelling concept of measuring the parking volume and parking duration for several landuses within the city so that they can be used as the input to predict the parking revenue of local authority. This parking model is expected to support the parking system revenue collecting of local authorities.

Additionally, by the existence of parking system collecting method, the parking operator and investor can make their financial planning accurately, while the local authority can easily predict their future income base on the existing and future parking facilities. Moreover, local authorities can eliminate or at least minimize the parking lost revenue (parking fee and parking tax) so that more fund for local income (bahasa: Pendapatan Asli Daerah, PAD) will be achieved. The flowchart of the conceptual idea is shown in Figure 1.

The goal of this paper is to suggest the concept of modelling parking volume as well as parkir duration of vehicles within various landuses (Hotel, Apartment, 
Mall, Campus, Hospital, Train Station, Restaurant, Convention building, Office, Mixed used) related to the parking performances including turnover, accumulation, index, dynamic capacity and operational characteristic (operational duration) as well as physical variables including number of parking space and parking area.

\section{LITERATURE REVIEW}

Currently, parking research is mainly discussing about the need of future parking space as well as the performance of such existing parking space. Sutapa, Suthanaya and Suweda (2008) create model of the need of parking space of mall in Denpasar Bali, while Widhiastuti et.al (2013) analyse the need of parking space of campus in Kalimantan. Moreover, Khalid and Hamsa (2013) discussed about the performance of park and ride at LRT Putra Jaya terminal and Kelana Jaya Station in Malaysia.

However, there are already some researchs discuss a little bit about the potential parking revenue as conducted by Kartika and Himawan (2013) in which the potential revenue of on-street parking in Surabaya is analysed eventhough in that research the discussion about the progressive parking tariff is neglected. Hidayah and Widyastuti (2014) discussed about the potential parking revenue of Kabupaten Hulu Sungai Tengah for both onstreet and off-street parking. But this paper only discuss about one landuse only (market) with no discussion about the modelling and progressive tariff. While the revenue will depend on number of vehicle (volume) parked and parking duration if the progressive tariff applied. Therefore, it is important to have these two variables modelled. Here are summary of some research regarding parking facillities.

$$
\begin{aligned}
& P_{(\text {lot parking })}=\frac{1}{1+e^{-1.082 \times 1-2.185 \times 2+1.393 \times 3+0.449 \times 4}+e^{-0.228 \times 1-1.215 \times 2+1.160 \times 3+0.002 \times 4} \ldots \ldots \ldots . . .(1)} \\
& P(\text { garage parking })=\frac{e^{-1.082-1.154 \times 1-2.185 \times 2+1.393 \times 3+0.449 \times 4}}{1+e^{-1.082-1.154 \times 1-2.185 \times 2+1.393 \times 3+0.449 \times 4}+e^{-0.228 \times 1-1.215 \times 2+1.160 \times 3+0.002 \times 4}} \\
& P_{\text {(onstreet })}=\frac{e^{-0.228 \times 1-1.215 \times 2+1.160 \times 3+0.002 \times 4}}{1+e^{-1.082-1.154 \times 1-2.15 \times 2+1.393 \times 3+0.449 \times 4}+e^{-0.228 \times 1-1.215}} \\
& \text { (onstreet })=\frac{e^{-0.228 \times 1-1.215 \times 2+1.160 \times 3+0.002 \times 4}}{1+e^{-1.082-1.154 \times 1-2.185 \times 2+1.393 \times 3+0.449 \times 4}+e^{-0.228 \times 1-1.215 \times 2+1.160 \times 3+0.002 \times 4}}
\end{aligned}
$$

where :

$\mathrm{X} 1$ = availability on street parking,

$\mathrm{X} 2$ = availability lot parking,

$\mathrm{X} 3$ = parking time in afternoon, and

$\mathrm{X} 4=$ income

\subsection{Parking as the Demand Restriction Instrument}

The need of parking space is ussually design to meet the demand occured, while the demnd itself is calculated based on several variables depending on the type of landuses served. The new paradigm of parking space supply is as the instrument to limit the uses of vehicle itself as found in many developed country. However the restriction programme can not be a stand alone programme but it need to be supported with other mandatory programme i.e. the reliable alternative mode of transportation, in this case good public transport facilities (AT, 2016). In most developed countries, this paradigm, can cause the reduction of utilization of private vehicle in significant number (Darmaningtyas, 2011).

\subsection{Analysis of Parking Performance and the Need of Parking Space}

Many reasearchs on the need of parking space as well as their technical performances (duration, volume, dynamic capacity, index, turnover and capacity) are found, those involve different locations. Those are including Machsus and Mukafi (2011) with malls in Surabaya as the location, Sutapa, Suthanaya, and Suweda (2008) with malls in Denpasar as the location, Khalid and Hamsa (2013) with LRT station in Malaysia as the location, Widhiastuti, Priyadi and Akhmadi (2013) with the polytechnic campus in Pontianak as the location, 


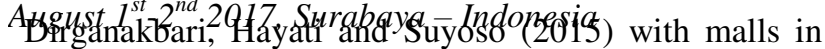
Jember as the location.

\subsection{Economic and Financial aspect of Parking Facility}

The research regarding the financial aspect of parking facility is relating to the potential on-street parking revenue in Surabaya is conducted by Kartika A.A.G and A. Himawan (2013) in which the model of potential parking revenue are shown below.

$\mathrm{Y}=1746232 \mathrm{x}$ (if the parking tariff based on

Local Law (bahasa: Perda) no. 1/2009)

$=2608238 \mathrm{x}$ (if the parking tariff based on the real charged which higher than stated in local law)

$\mathrm{Y}=2807819 \mathrm{x}$ (if the progressive parking tariff is applied)

where:

$Y \quad$ : potential annual revenue (IDR/yr)

$x \quad$ : the length of on-street parking available

Additionally, Hidayah and Widyastuti (2014) analyse the difference parking revenue between the target and realisation of market building in Kabupaten Hulu Sungai Tengah Kalimantan Selatan. While Rizki, Kosakoy and Joewono (2014) the willingness of students to pay parking fee in their campus. Samples are taken from both car user and motorcycle user at Parahyangan Chatolic and the attribute considered in the analysis are including parking duration and the availability of parking equipments.

Meanwhile, Mantecchini (2015) discuss about the decision making of the location future parking facility development of airport in Italia. The alternative locations is separated from the existed airport. The issues discussed here is that farther parking location will make the less passenger to use that parking facility. On the other hand farther location has some advantages including lower land price and less congested eventhough shuttle service must be provided as the consequences. The proving of shuttle service, in this case by using bus will be calculated as the additional cost and the shuttle service tariff will be calculated as the restriction.

The decision of best parking location based on the trade off between demand and operational cost of parking facility including shuttle bus. The method of

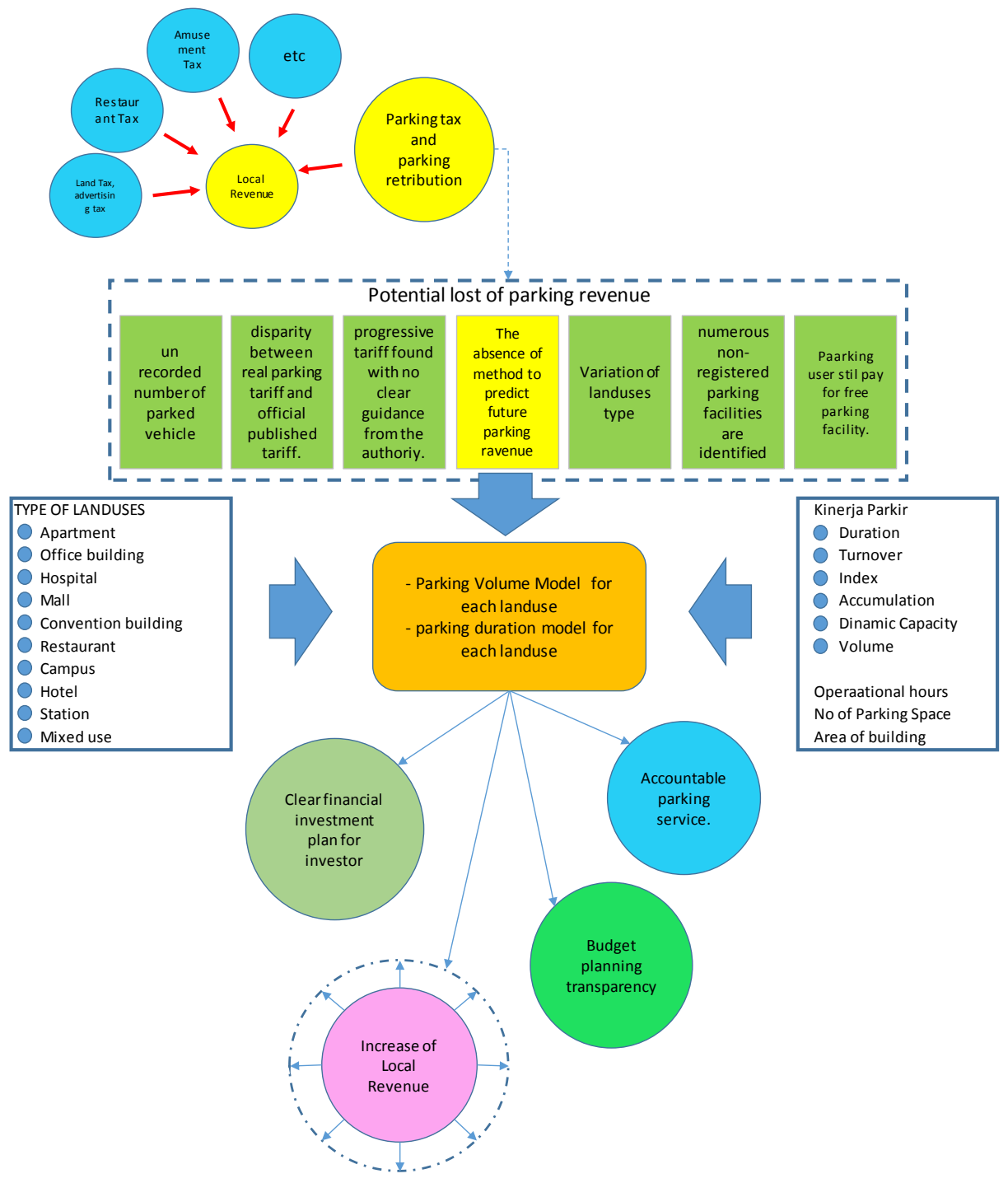

Figure 1. Conceptual Idea 
analysis is carried out by optimization of spplying parking space, parking tariff, and parking operational cost (finding parking space cost, shuttle bus cost wih specific headway, capacity and utilization factor).

Different perspective regarding financial aspect of parking is shown by Arditia, R. dan D.A. Nuswantara (2013) in which the contribution as well as the efectiveness of local tax as the local revenue is analysed since parking tax is one of the local tax component. The contribution criteria is measured from Team of Litbang Depdagri-Fisipol UGM (1991) while the efectivenes is measured by standard value taken from Kepmendagri (Decree of Minister of Internal Affair Republic Indonesia) No. 690.900-327/1996.

\subsection{Applied Technology in Parking service and operation}

Many researchs regarding the applied technology of parking service and operation has been conducted, one of them is carried out by Birell et. al. (2015) discussing the impact of parking layout as well as driver behaviour to the position of wireless battery recharge aquipment when electrical car is used. The result shows that lateral position is better than longitudinal position in terms of accuracy of vehicle position. However, overall only $5 \%$ of vehicles is in their accurate position when they are recharged.

The other one is Renuka and Dhanalkshmi (2015) investigate the android based application to find vacant parking space together with the real time tariff accordingly. The finding process based on the slot allocation method while the payment method used is RFID (Radio Frequency Identification Device). Within this application, it is also possible to book available vacant parking space based on nearest location and the cheapest tariff.

Meanwhile, Banerjee and Al-Qaheri (2011) model the availability of parking space in small town, in this case Mauritius, in which they also develop software that can be installed in cell-phone so that parking user can easily find available parking space nearby.

\subsection{Parking in Technical Point of Views}

The technical performances of parking facilities according to Hobbs (1984) are as follows:
3. Turnover

4. Parking Index/Occupancy

5. Parking Duration

6. Capacity and Dynamic Capacity

\subsection{Parking in Legal Point of Views of Indonesia}

\section{A. Traffic and Transportation Act No 22/1999}

Art 43 explain about base regulation regarding parking issues, one of them is that the public parking space is only possible to be installed outside ROW of road, however it is possible to installed parking facility within the the ROW of the road but this is can only be applied to either Regency (Bahasa: kabupaten) road or village (bahasa: desa) road.

B. Surabaya's Major Decree No. 37/2015 regarding The Changing of Retribution for Parking Tariff

The changing of retribution for paring tariff in city of Surabaya is regulated by Major Decree No 37/2015 which can be summarised in Tabel 1.

\section{PROPOSED CONCEPTUAL OF ANALYSIS}

\subsection{Parking performance analysis and type of landuses modelled}

Before creating the model, the analysis of parking performance of each landuses must be carried out first. The parking performance analysis will include parking accumulation, parking volume, turnover parking, parking index, dynamic capacity and parking duration. They will cover these following types of landuses; mall, office, apartment, shopping-house, hotel, restaurant, hospital, station, convention building and mixed use. The analysis will be devided into two different group of day including weekday and weekend.

\subsection{Model of Parking Performance (duration and volume) of each Landuse}

As explained before that the number of parking revenue (retribution and parking tax) will depend on the two technical variables and the tariff of parking services. Those two technical variables are parking volume and parking duration. Since the tariff is only depending on the local authorities, therefore, these two variables will

Table 1. Parking Retribution

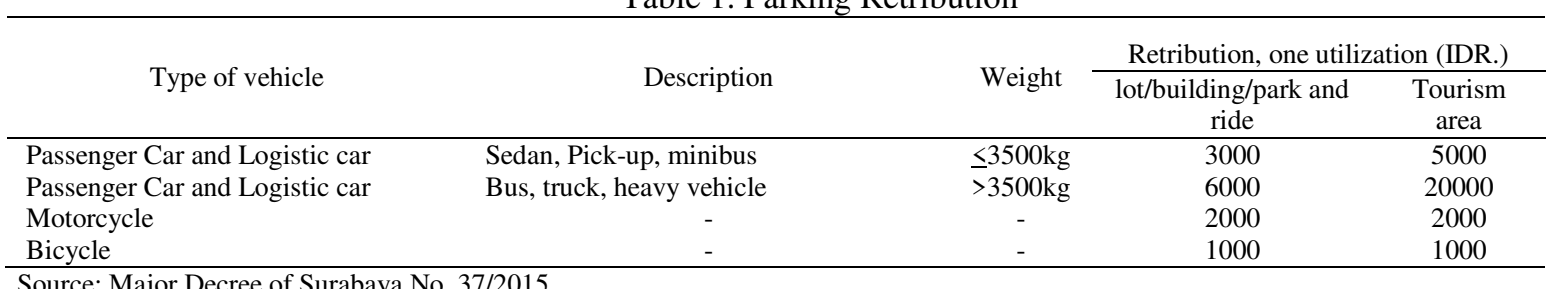

Source: Major Decree of Surabaya No. 37/2015

1. Parking Accumulation

2. Parking Volume 
The Third International Conference on Civil Engineering Research (ICCER) August $1^{\text {st }}-2^{\text {nd }} 2017$, Surabaya - Indonesia

\begin{tabular}{|c|c|c|c|c|c|c|}
\hline No & Author & Year & Type & Title & Discussion & Gap \\
\hline 1 & Machsus and Mukafi & 2011 & Proceeding Seminar & $\begin{array}{l}\text { Kajian Kebutuhan Ruang Parkir pada Mall } \\
\text { Galaxy di Kota Surabaya }\end{array}$ & $\begin{array}{l}\text { The performance of parking facility of Mall in } \\
\text { Surabaya (Galaxy Mall) }\end{array}$ & $\begin{array}{l}\text { No Model on parking duration and parking } \\
\text { volume, other landuses type is not } \\
\text { discussed. No discussion about parking } \\
\text { revenue }\end{array}$ \\
\hline 2 & $\begin{array}{l}\text { Banerjee S. and Al- } \\
\text { Qaheri H. }\end{array}$ & 2011 & Journal & $\begin{array}{l}\text { An Intellegent Hybrid Scheme for Opimizing } \\
\text { Parking Space: a Tabu Metaphore and } \\
\text { Rough Set Based Approach }\end{array}$ & $\begin{array}{l}\text { Model the availability of parking space in small } \\
\text { town, in this case Mauritius city }\end{array}$ & $\begin{array}{l}\text { No model on parking performance as well as } \\
\text { no discussion about the revenue. }\end{array}$ \\
\hline \multirow[t]{4}{*}{3} & $\begin{array}{l}\text { Kartika AAG and } \\
\text { Himawan A. }\end{array}$ & 2013 & Proceeding Seminar & $\begin{array}{l}\text { Studi Pendapatan dari Sektor Parkir Jalan } \\
\text { Umum Kota Surabaya }\end{array}$ & $\begin{array}{l}\text { Potential revenue of on-street parking for only year } \\
2011 \text { only. }\end{array}$ & $\begin{array}{l}\text { model can not be applied when parking tariif is } \\
\text { changed. }\end{array}$ \\
\hline & & & & & $\begin{array}{l}\text { Model developed based on the length of the } \\
\text { parking facility on the street. }\end{array}$ & $\begin{array}{l}\text { Various scenario of progressive tariff can not be } \\
\text { accomodated }\end{array}$ \\
\hline & & & & & $\begin{array}{l}\text { the calculation of potential lost of revenue based } \\
\text { on the different tariff between published official tariff } \\
\text { and real tariff as well as only registered location is } \\
\text { calculated }\end{array}$ & the model for off-street parking is excluded \\
\hline & & & & & & $\begin{array}{l}\text { No parking model based on the parking } \\
\text { performance is created so that can be used for } \\
\text { the future. }\end{array}$ \\
\hline \multirow{7}{*}{5} & $\begin{array}{l}\text { Hidayah S., and Widyastuti } \\
\text { H. }\end{array}$ & 2014 & Theses & $\begin{array}{l}\text { Studi Potensi Pendapatan dari Sektor On-Street } \\
\text { Parking dan Off-Street Parking di Kabupaten } \\
\text { Hulu Sungai Tengah }\end{array}$ & $\begin{array}{l}\text { Potential revenue of on-street and off-street parking } \\
\text { for only year } 2013 \text { only. }\end{array}$ & $\begin{array}{l}\text { model can not be applied when parking tariif is } \\
\text { changed. }\end{array}$ \\
\hline & & & & & $\begin{array}{l}\text { Model developed based on the length of the } \\
\text { parking facility on the street. }\end{array}$ & $\begin{array}{l}\text { Various scenario of progressive tariff can not be } \\
\text { accomodated }\end{array}$ \\
\hline & & & & & $\begin{array}{l}\text { Only discuss one landuse, in ths case market } \\
\text { building. }\end{array}$ & $\begin{array}{l}\text { No parking model based on the parking } \\
\text { performance is created so that can be used for } \\
\text { the future. }\end{array}$ \\
\hline & & & & & & $\begin{array}{l}\text { The variable of parking space, operational hours } \\
\text { and the area of building are not considered. }\end{array}$ \\
\hline & $\begin{array}{l}\text { Sutapa IK, Suthanaya PA, } \\
\text { and Suweda IW }\end{array}$ & 2008 & Journal & $\begin{array}{l}\text { Analisis Karakteristik dan Pemodelan } \\
\text { Kebutuhan Parkir Pada Pusat Perbelanjaan di } \\
\text { Kota Denpasar }\end{array}$ & $\begin{array}{l}\text { Analyse the technical performance of parking } \\
\text { facility of mall in Denpasar }\end{array}$ & no discussing about paring revenue \\
\hline & & & & & $\begin{array}{l}\text { Analyse the adiitional need of parking space to } \\
\text { meet the parking demand }\end{array}$ & $\begin{array}{l}\text { No Model on parking duration and parking } \\
\text { volume, other landuses type is not discussed.. }\end{array}$ \\
\hline & & & & & $\begin{array}{l}\text { modelling the need of parking space based on } \\
\text { these following variable; no of employee and part } \\
\text { time employee }\end{array}$ & \\
\hline \multirow[t]{2}{*}{6} & $\begin{array}{l}\text { Khalid UA and Hamsa } \\
\text { AAK }\end{array}$ & 2013 & Proceeding Seminar & $\begin{array}{l}\text { Parking Utilization and Ride Facility at Public } \\
\text { Transportation Terminals }\end{array}$ & $\begin{array}{l}\text { Analyse the technical performance of parking } \\
\text { sacility at two LRT station in Malaysia }\end{array}$ & $\begin{array}{l}\text { No Model on parking duration and parking } \\
\text { volume, other landuses type is not discussed.. }\end{array}$ \\
\hline & & & & & $\begin{array}{l}\text { Analyse the adiitional need of parking space to } \\
\text { meet the parking demand which currently the } \\
\text { parking index already achieve } 90 \%\end{array}$ & \\
\hline \multirow[t]{2}{*}{7} & $\begin{array}{l}\text { Widhiastuti RE, Priyadi RE } \\
\text { and Akhmadi }\end{array}$ & 2013 & Journal & $\begin{array}{l}\text { Evaluasi dan Analisis Kebutuhan Ruang Parkir } \\
\text { di Kampus Politeknik Negeri Pontianak }\end{array}$ & $\begin{array}{l}\text { Analyse the technical performance of parking } \\
\text { facility of campus }\end{array}$ & $\begin{array}{l}\text { No discussion regarding parking tariff and } \\
\text { revenue }\end{array}$ \\
\hline & & & & & $\begin{array}{l}\text { Analyse the adiitional need of parking space to } \\
\text { meet the parking demand }\end{array}$ & $\begin{array}{l}\text { No Model on parking duration and parking } \\
\text { volume, other landuses type is not discussed.. }\end{array}$ \\
\hline 8 & Arditia $\mathrm{R}$ and Nuswantara & 2013 & Journal & $\begin{array}{l}\text { Analisis Kontribusi dan Efektivitas Pajak Daerah } \\
\text { Sebagai Sumber Pendapatan Asli Daerah Kota } \\
\text { Surabaya }\end{array}$ & $\begin{array}{l}\text { To discuss the contribution share of parking tax of } \\
\text { all local tax as well as its efectiveness within the } \\
\text { period of 2007-2011. }\end{array}$ & $\begin{array}{l}\text { No discussion about how to determina the tax as } \\
\text { well as no discussion about technical parking } \\
\text { performance }\end{array}$ \\
\hline 9 & $\begin{array}{l}\text { Dirganakbari MI, NN } \\
\text { Hayati and H Suyoso }\end{array}$ & 2015 & Journal & \begin{tabular}{|l|} 
Penyediaan Fasilitas Parkir pada Pusat \\
Perbelanjaan Roxy Square di Kabupaten \\
Jember
\end{tabular} & $\begin{array}{l}\text { Discuss the diffrent need of parking space } \\
\text { between weekday and weekend for mall in } \\
\text { Jember }\end{array}$ & $\begin{array}{l}\text { No Model on parking duration and parking } \\
\text { volume, other landuses type is not } \\
\text { discussed. No discussion about parking } \\
\text { revenue }\end{array}$ \\
\hline 10 & $\begin{array}{l}\text { Rizki M, CM Kosakoy } \\
\text { dan TB Joewono }\end{array}$ & 2014 & Prosiding Seminar & $\begin{array}{l}\text { Eksplorasi Kesediaan Membayar Parkir } \\
\text { Mahasiswa Menggunakan Stated } \\
\text { Preference }\end{array}$ & $\begin{array}{l}\text { Discuss about the willingness to pay of } \\
\text { students regarding parking service in their } \\
\text { university }\end{array}$ & $\begin{array}{l}\text { No Model on parking duration and parking } \\
\text { volume, other landuses type is not } \\
\text { discussed. No discussion about parking } \\
\text { revenue }\end{array}$ \\
\hline 11 & $\begin{array}{l}\text { Renuka R and S. } \\
\text { Dhanalakshmi }\end{array}$ & 2015 & Journal & $\begin{array}{l}\text { Android-Based Smart Parking System Using } \\
\text { Slot Allocation and Reservations }\end{array}$ & $\begin{array}{l}\text { Creating android based application to find } \\
\text { parking space as well as the real time parking } \\
\text { tariff accordingly. }\end{array}$ & $\begin{array}{l}\text { No Model on parking duration and parking } \\
\text { volume. No discussion about parking } \\
\text { revenue as well as technical performance of } \\
\text { parking facility }\end{array}$ \\
\hline 12 & Luca Mantecchini & 2015 & Journal & $\begin{array}{l}\text { Optimization of Airport Parking Facilities } \\
\text { Size, Location and Construction }\end{array}$ & $\begin{array}{l}\text { The analysis to decide best remote location of } \\
\text { new parking facility of an airport in Italia. The } \\
\text { analysis is based on economic point of views. }\end{array}$ & $\begin{array}{l}\text { No Model on parking duration and parking } \\
\text { volume, other landuses type is not } \\
\text { discussed. No discussion about parking } \\
\text { revenue }\end{array}$ \\
\hline 13 & $\begin{array}{l}\text { Birrell S.A., Wilson D., } \\
\text { Yang C.P., Dhadyalla } \\
\text { G., Jennings P. }\end{array}$ & 2015 & Journal & $\begin{array}{l}\text { How Driver Behaviour and Parking } \\
\text { Alignment Affects Inductive Charging } \\
\text { Systems for Electric Vehicle }\end{array}$ & $\begin{array}{l}\text { Discuss about the impact of parking layout and } \\
\text { driver behaviour to the posistion of wireless } \\
\text { battery charger equipment for electric car. }\end{array}$ & $\begin{array}{l}\text { No Model on parking duration and parking } \\
\text { volume. No discussion about parking } \\
\text { revenue as well as technical performance of } \\
\text { parking facility }\end{array}$ \\
\hline 14 & $\begin{array}{l}\text { Mudjanarko S. W, H. } \\
\text { Sulistio, L. Djakfar, and } \\
\text { A. Wicaksono } \\
\end{array}$ & 2013 & Journal & \begin{tabular}{|l|} 
Behaviour Model of Motor Cycle User in \\
Selecting Parking Location (Case study \\
in Surabaya City of Indonesia)
\end{tabular} & $\begin{array}{l}\text { Discuss about the probability of choosing } \\
\text { parking location for motorcycle. There are } \\
\text { three possible options, including on-street } \\
\text { parking, garage parking (off-street) and lot } \\
\text { parking (off-street) }\end{array}$ & $\begin{array}{l}\text { No Model on parking duration and parking } \\
\text { volume. No discussion about parking } \\
\text { revenue as well as technical performance of } \\
\text { parking facility }\end{array}$ \\
\hline 15 & Auckland Trasnport & 2016 & Guidance & $\begin{array}{l}\text { Auckland Transport Price, Adjustment } \\
\text { Policy Parking Buildings, Auckland CBD }\end{array}$ & $\begin{array}{l}\text { To discuss parking facility as the } \\
\text { instrument to restrict vehicle visitation to } \\
\text { CBD }\end{array}$ & $\begin{array}{l}\text { No detail discussion about technical parking } \\
\text { performance. }\end{array}$ \\
\hline 16 & Darmaningtyas & 2011 & Monograph & Parkir dan Pembatasan Mobil & $\begin{array}{l}\text { To discuss parking facility as the } \\
\text { instrument for trip restritcor }\end{array}$ & $\begin{array}{l}\text { No detail discussion about technical parking } \\
\text { performance. }\end{array}$ \\
\hline
\end{tabular}


Table 3 Dependent Variabel and Independent Variable.

\begin{tabular}{|c|c|c|c|}
\hline \multicolumn{2}{|c|}{ Dependent Variable, Y } & \multicolumn{2}{|c|}{ Independent Variables, $\mathrm{Xi}$} \\
\hline \multirow[t]{8}{*}{ Volume parkir } & \multirow[t]{8}{*}{ Y } & Turnover & $\mathrm{X} 1$ \\
\hline & & Index & $\mathrm{X} 2$ \\
\hline & & Dynamic Capacity & $\mathrm{X} 3$ \\
\hline & & Avearge Duration & $\mathrm{X} 4$ \\
\hline & & Accumulation & $\mathrm{X} 5$ \\
\hline & & Parking space & X6 \\
\hline & & Operational hours & $\mathrm{X} 7$ \\
\hline & & Area of building & $\mathrm{X} 8$ \\
\hline \multicolumn{4}{|c|}{$\begin{array}{l}\text { Duration }(\% \text { duration of } \\
\text { total }), Y i\end{array}$} \\
\hline$<5 \min$ & Y1 & Turnover & $\mathrm{X} 1$ \\
\hline $5-120 \mathrm{~min}$ & $\mathrm{Y} 2$ & Index & $\mathrm{X} 2$ \\
\hline $2-3 \mathrm{hrs}$ & $\mathrm{Y3}$ & Dynamic Capacity & $\mathrm{X} 3$ \\
\hline 3-4 hrs & Y4 & Volume & $\mathrm{X} 4$ \\
\hline 4-5 hrs & Y5 & Accumulation & $\mathrm{X} 5$ \\
\hline $5-6 \mathrm{hrs}$ & Y6 & Parking space & $\mathrm{X} 6$ \\
\hline 6-7 hrs & Y7 & Operational hours & $\mathrm{X} 7$ \\
\hline $7-8 \mathrm{hrs}$ & Y8 & Area of building & $\mathrm{X} 8$ \\
\hline$>8 \mathrm{hrs}$ & Y9 & & \\
\hline
\end{tabular}

modelled and used as the dependent variables. For volume model the independent variable will be turnover, index, dynamic capacity, average duration, accumulation as well as the physicaal variable (number of parking space and the area of building) and operational variable (operational hours).

Duration model will be in form of percentage of duration of each group of duration as the dependent variable to accomodate the progressive tariff that may occured, while the independent variable will be as follow; turnover, index, dynamic capacity, volume, accumulation as well as the physical variables (number of parking space and the area of building) and operational variable (operational hours). The independent and dependent variable for the model is summarised in Table 3. Regression of principal component will be used to create the models.

Based on Table 3 above the model made for each landuses, each landuses will have two model for weekdays and weekend. The bold independent variables (paking space, operational hours, area of building) can be easily identified while the others need to be found. By the existence of these models as well as the published official parking tariff, the local authority can easily predict the parking revenue annually so that the lost of parking revenue can be eliminated or at least can be minimised.

\section{REFERENCES}

[1] Arditia R. dan Nuswantara D.A. (2013) Analisis Kontribusi dan Efektivitas Pajak Daerah Sebagai Sumber Pendapatan Asli Daerah Kota Surabaya, e-journal dipublikasikan oleh Alim Sumarno 17 Mei 2013, retrieved from http://id.scribd.com/doc/141986298/ANALISIS-

KONTRIBUSI-DAN-EFEKTIVITAS-PAJAK-DAERAHSEBAGAI-SUMBER-PENDAPATAN-ASLIDAERAHKOTA-SURABAYA\#scribd, retrieved in $18 \mathrm{Mei}$ 2015.

[2] AT (2016) Auckland Transport Price, Adjustment Policy Parking Buildings, Auckland CBD, Auckland Transport, https://at.govt.nz/media/359818/AT-Off-Street-ParkingPrice-Policy.pdf, diunduh pada tanggal 15 Mei 2016.

[3] Banerjee S. and Al-Qaheri H. (2011) An Intellegent Hybrid Scheme for Opimizing Parking Space: a Tabu Metaphore and Rough Set Based Approach, Egyptian Informatics Journal 12, 9-17, Cairo University.

[4] Beritasurya (2012) Pendapatan Parkir Rendah, Digemol Jukir Nakal, 02-02-2012, retrieved from http://beritasurabaya.net/index_sub.php?category=4\&id=53 66, retrieved in 3 april 2015.

[5] Birrell S.A., Wilson D., Yang C.P., Dhadyalla G., Jennings P. (2015) How Driver Behaviour and Parking Alignment Affects Inductive Charging Systems for Electric Vehicle. Elsevier Journal, Transportation Research Part C.

[6] Darmaningtyas (2011) Parkir dan Pembatasan Mobil, diunduh pada tanggal 5 Maret 2016 .http://sriwiwoho.blogspot.co.id/2011/03/parkir-danpembatasan-mobil.html

[7] Dirganakbari MI, NN Hayati dan H Suyoso (2015) Penyediaan Fasilitas Parkir pada Pusat Perbelanjaan Roxy Square di Kabupaten Jember. Jurnal Transportasi, FSTPT, Vol 15, No 1. 
[8] Draper, N.R dan Smith, H.( 1992) Analisis Regresi Terapan, edisi kedua. Alih bahasa: Sumantri B. Jakarta: Gramedia

[9] Efendi, M. Mushonnif dan Purnomo, Jerry Dwi Trijoyo (2012) Analisis Faktor Konfirmatori untuk Mengetahui Kesadaran Berlalu Lintas Pengendara Sepeda Motor di Surabaya Timur, JURNAL SAINS DAN SENI ITS Vol. 1, No. 1, (Sept. 2012) ISSN: 2301-928X.

[10] Hakim, L. (2014) Kebocoran Pendapatan Parkir di Surabaya Capai $40 \%$ Sindonews, http://daerah.sindonews.com/read/927971/23/kebocoranpendapatan-parkir-di-surabaya-capai-40-1416720038, source: http://daerah.sindonews.com/read/927971/23/kebocoranpendapatan-parkir-di-surabaya-capai-40-1416720038 retrieved in 15th March 2015.

[11] Hidayah, S., dan H. Widyastuti (2014) Studi Potensi Pendapatan dari Sektor On-Street Parking dan Off-Street Parking di Kabupaten Hulu Sungai Tengah, Tesis Bidang Studi Manajemen Rekayasa Tranportasi, Program Studi Pasca Sarjana, Jurusan Teknik Sipil, FTSP, Institut Teknologi Sepuluh Nopember Surabaya.

[12] Hobbs F.D. (1984) Traffic planning and Engineering, Second edition Pergamon Press.

[13] Kartika, A.A.G. dan A. Himawan (2013) Studi Pendapatan dari Sektor Parkir Jalan Umum Kota Surabaya, Seminar Nasional IX-2013 Teknik Sipil ITS Surabaya, Peran Industri Konstruksi dalam Menunjang MP3EI (Masterplan Percepatan dan Perluasan Pembangunan Ekonomi Indonesia), Program Studi Pasca Sarjana, Jurusan Teknik Sipil, FTSP, Institut Teknologi Sepuluh Nopember Surabaya.

[14] Khalid U.A. dan A.A.K. Hamsa (2013) Parking Utilization and Ride Facility at Public Transportation Terminals, Proceedings of the Eastern Asia Society for Transportation Studies, EASTS, Vol.9, 2013

[15] Machsus dan Mukafi (2011) Kajian Kebutuhan Ruang Parkir pada Mall Galaxy di Kota Surabaya, Prosiding Seminar Nasional Aplikasi Teknologi Prasarana Wilayah (ATPW), 21 Juli 2011, ISBN: 978-979-18342-3-0. Program Studi Diploma Teknik Sipil, FTSP-ITS.

[16] Mardiasmo (2009) Perpajakan, Penerbit ANDI, Yogyakarta.

[17] Mantecchini L. (2015) Optimization of Airport Parking Facilities Size, Location and Construction, ARPN Journal Vol 10 No 2 February 2015

[18] Mudjanarko S. W, H. Sulistio, L. Djakfar, and A. Wicaksono (2013) Behaviour Model of Motor Cycle User in Selecting Parking Location (Case study in Surabaya City of Indonesia), Journal of Basic Applied Sciencific
Research, 3(7)842-846, 201., ISSN 2090-4304. Diunduh pada 18 April 2016, http://textroad.com/pdf/JBASR/J.\%20Basic.\%20Appl.\%20S ci.\%20Res.,\%203(7)842-846,\%202013.pdf.

[19] Rizki M., CM Kosakoy dan TB Joewono (2014) Eksplorasi Kesediaan Membayar Parkir Mahasiswa Menggunakan Stated Preference Prosiding FSTPT 17, International Symposium, 22-24 August 2014, Universitas Jember Jawa Timur.

[20] Renuka R and S. Dhanalakshmi (2015) Android-Based Smart Parking System Using Slot Allocation and Reservations, ARPN Journal of engineering and applied siences Vol 10, No 7, April 2015

[21] Suarasurabaya.net (2015) Kelana Kota, DPRD Surabaya Soroti Kenaikan Tarif Parkir Mal. Retrieved from http://kelanakota.suarasurabaya.net/news/2015/148082DPRD-Surabaya-Soroti-Kenaikan-Tarif-Parkir-Mal. Retrieved in 3rd March 2015

[22] Sutapa I K., P. A. Suthanaya, I W. Suweda (2008) Analisis Karakteristik dan Pemodelan Kebutuhan Parkir Pada Pusa Perbelanjaan di Kota Denpasar, Jurnal Ilmiah Teknik Sipil Vol. 12, No. 2, Juli 2008

[23] Thornton, J. F., M.D., Closson, Tom, B.A.Sc, M.B.A., Meagher, T., M.D., \& Johnsen, J. H., M.D. (2012). Hospital parking fees. Canadian Medical Association.Journal, 184(4), 439-40. Retrieved from http://search.proquest.com/docview/953522303?accountid= 25704

[24] Widhiastuti R., E. Priyadi dan Akhmadi (2013) Evaluasi dan Analisis Kebutuhan Ruang Parkir di Kampus Politeknik Negeri Pontianak, Jurnal Teknik Sipil Untan, Voume 13 No. 1, Juni 2013, Halaman 161-176.

[25] Undang-Undang Republik Indonesia No. 14 Tahun 2009 tentang Lalu Lintas dan Angkutan Jalan.

[26] Undang-Undang Republik Indonesis No. 28 Tahun 2009 tentang Pajak Daerah

[27] Peraturan Daerah Pemerintah Kota Surabaya No 1. Tahun 2009 tentang Penyelenggaraan Perparkiran dan Retribusi Parkir Kota Surabaya

[28] Peraturan Daerah Pemerintah Kota Surabaya No. 4 Tahun 2011 tentang Pajak Daerah

[29] Peraturan Walikota Surabaya No. 36 Tahun 2015 Tentangg Perubahan Tarif Retribusi Pelayanan Parkir di Tepi Jalan.

[30] Peraturan Walikota Surabaya No.37 Tahun 2015 Tentang Perubahan Tarif Retribusi Tempat Khusus Parkir. 